\title{
Islam and Social Engineering
}

\section{The successful person is not one who has mountain of wealth. But the the one who has excellent social relations in the society}

Farooq Ahmad Bakloo ${ }^{1}$, Miss Asma ${ }^{2}$

${ }^{1}$ Research Scholar Department of Political science Kumaun University Nainital S.S.J. Campusl Almora, Uttarakhand

${ }^{2}$ Senior Research Fellow, UGC, Department of Education Kumaun University Nainital S.S.J Campus Almora.

Email: farooqmajeed19@gmail.com

\begin{abstract}
The man by nature cannot live in the isolation Allah has created the man such a way that hel she cannot live in the separation. Even when Allah created, the Hazrat Adam Allah created his partner Hazrat Hawa. It is a well-known fact that human being cannot spend the life in separation; a man is by nature is a social and cannot live without the society. Aristotle called society is essential for the development of the of human beings. The biology of the human being is such that it is tough for the humans to live in isolation forever. Islam is the religion, which is calling towards the principles of peace and focuses on all the spheres of the life; it talks about the Religious teachings, Social Teachings, Moral teachings, Economic teachings, and Governance teachings. In this easy, we highlight the Islamic perspective on society. Before moving ahead, it is essential to know the very meaning of word society; the word society means as "aggregate of people living together in a more or less ordered."
\end{abstract}

Keywords: Social Relations, Social Engineering, Women Empowerment and Islam

\section{Introduction}

As we know in the society, the human beings communicate with each other for the different needs, so in this entire process, these humans have responsibilities and rights towards each other. Therefore, in this backdrop, the Islam not only presents the teachings how to behave with the fellow beings but also educates the human beings through the Noble Quran and the Prophet of Islam (PBUH) that how to act with the other creation of Allah.

The social teachings start from the home in the teachings of the Islam the responsibility of earning is giving to the males, and they are the protectors and maintainers of the women. However, the females can also do business under the circle and rules of the Islam, 
as the first international business executive was the first loved wife (Hazarat Khadija R.A) of the Prophet (PBUH) of Islam as she was trading with the different states during that time.

\section{Responsibilities of Husbands towards their Wives}

Nowadays due to the ignorance among the Muslim societies, many husbands beat their wives very often on little things. These all activities are against the authentic teachings of the Sunnah. The domestic violence is against the teachings of Islam the last sermon of the Prophet strongly focus on the women rights and instruct the followers that they will treat their wives with respect. Islam is the religion which emphases on the gender justice in some matters women has given importance and in some matters male has given weight. The honour of the women is one of the main subjects of the Quran there is the full chapter by the name of women (An- Nisa, chapter four) in the Noble Quran. The Noble Quran has closed all those doors, which harm the chaste, and dignity of the women, as women are the social engineer who plays a vital role in the building of the society.

Therefore, it is not allowed, for the Muslim men to maltreat his wave nowadays the debate of talaq has taken the mass storm in the media houses. Mostly those people are discussing at these media houses who has not authentic knowledge about the system of Talaq.

The Quran has given full detail in this manner in some verse of chapter two AlBaqarah), (chapter four An- Nisa) and there is a particular chapter (65) in the Noble Quran whose name is "Sura Talaq."

It is the need of the hour to read these chapters of the Noble Quran with understand for the betterment of the society.

The overall summary concerning the responsibilities of husbands towards their wives are as:

- Provide the sustenance to the wife.

- Fulfil the physical requirements of the wife.

- Respecting and listening to the wife.

- Respect the parents and beloveds of the wife.

- Protect the wife.

- The husband should not beat the wife.

- Do not admonish the wife outside the home or in front of others.

- Speaking kind and with right words to the wife.

- The husband should not disclose the secrets of the wife. 
- Expressing the appreciation to the wife.

\section{Responsibilities of Fathers towards their Children}

The Islam instructs the fathers that they will impart good manners to the children and give them right names, educate them about the Quran and Islamic monotheism, treat them with love and mercy, show them how to earn Halal way of earning, and give them better education concerning both here and hereafter and search good and beautiful spouse for them.

\section{Responsibilities of Children towards their Parents}

Moreover, at the same time, the Islam instructs the children that they will respect the parents and follow their instructions in the circle of the Quran and authentic Sunnah and do not abuse them in any form. Islam is very concern about the rights of parents regarding the respect of Parents it is mentioned in the eleven times in the Noble Quran. The chapters and verses of the Noble Quran in which Allah has mentioned the importance and Respect of parents are as (Quran 17:23-24), (Quran 29:8 \& Quran 46:15), (Quran 2:83), (Quran 4:36), (Quran 6:151).

The paradise lies under the feet of the mother but in the contemporary times, we have forgotten the teachings as we are following the "popular culture" of the west that looks very attractive but actually, that popular culture is composed of the elements of poison, which has destroyed the most family sprit in most of the parts of the world.

\section{Responsibilities towards the Neighbors}

Allah says in the Noble Quran that

"Worship Allah and associate nothing with him, and to parents do good, and to relatives, orphans the needy, the near neighbour, the neighbour farther away, the companion at your side, the traveller and those whom your right hands possess Allah indeed does not like those who are self- deluding and boastful ( 4:36).

It is apparent from the above verse of the Noble Quran that apart from having absolute belief in the oneness of the Allah, one has to fulfil the privileges of one's family members like parents and relatives take care of orphans and the poor in surroundings both close and distant neighbours and travellers.

After coming out from the family, our interaction starts with the individuals living around us these people living around us are called neighbours. The Islam has instructed the followers that treat the neighbours with love and respect.

Concerning the rights of the neighbours, the Prophet of Islam said that By Allah he is not a believer by Allah he is not a believer by Allah he is not a believer 
It was asked who is that $\mathrm{O}$ Messenger of Allah he said one whose neighbour does not feel safe from his evil.

From this saying of the Prophet of Islam (PBUH), it is clear that one cannot achieve a status of good and faithful Muslim until or unless it does not guarantee that, its actions are not defying the fundamental requirement of the safety of its neighbours.

The prophet of Islam PBUH teach his followers that give the presents to the neighbours as the Prophet of Islam said that

O Muslim women No one of you should consider insignificant (a gift) to give her neighbour even if it is (a gift of) the trotters of a sheep.

Abdullah Ibn Umar (RA) and Aisha (RA) related the Noble Prophet Hazrat Muhammad PBUH saying as:

Angel Jibril (Peace be upon him) kept exhorting me about the rights of neighbour so much that I thought that the neighbour might be included as one of the heirs.

Therefore, Islam gives such importance to the neighbours as dealing with the respect and goodness with these neighbours is the sign of Good Muslim.

Among the rights of one Muslim over the neighbour areas:

- Greet him with the Islamic greeting.

- Visit during the time of illness.

- Help them during needy times and calamity.

- Offer congratulations at the times of happiness.

- To increase the love gives them gifts.

- Help them financially during the times of need.

- Do not be jealous of the activities of the neighbours.

- Guide the neighbour towards those things that are beneficial to him for both in religious and world affairs.

\section{Rights of Muslims towards the Non-Muslims}

Nowadays the anti-Muslim forces across the world are busy to speak and spread the hatred voices against the Islam through a variety of platforms and spread the hate against the Muslims. These forces misquote the verses of the Quran and try to associate the Islam as Religion of violence. The people who do not know the Islam come in this propaganda and the politicians of the time take its entire advantage to fulfil their political means.

Coming on the central theme that Islam divides the Non-Muslims into two groups one who fight and harm the Muslims for this group the Islam has provided the ways that how to 
deal with this group in a defence. Even the war times with this group the Allah guides the Muslims in the Noble Quran as

"and if anyone of the disbeliever seeks your protection then grant him protection, so that he may hear the word of Allah and then to escort him to where he can be secure, that is because they are men who know not (Al Quran 9:6).

It is not allowed for the Muslims to disrespect their religious places as Allah says in the Noble Quran

"And insult not those whom they disbelievers worship besides Allah" (Al Quran 6: 108).

The Islam gives the code of conduct and instructions to the Islamic army during the war times as

The prophet of Islam PBUH said that

- Do not cut the trees.

- Do not kill old people.

- Do not destroy a temple or church.

- Do not demolish the building.

- Do not kill those who surrendered.

- Do not kill who ran away.

- Do not kill a woman.

- Do not kill a sick person.

- Do not kill a monk or a priest.

- Do not disfigure the dead.

- Do not kill an animal except for eating.

- Be kind to the prisoners and feed them.

- Do not enforce Islam.

The other group are those who are friendly with the Muslims and are not fighting with Muslims. The Quran guides that behave with them kindly and justice as the Allah says that

"Allah does not forbid you to deal justly and kindly with those who fought not against you on account of religion nor drove you out of your homes. Verily, Allah loves those who deal with equity (Al Quran 60: 08).

When one studies, Islam intensely one can find the four types of models these models are beneficial for those who are living in the multicultural societies. It is urgent for us 
to implement these models at personal and organisational level. These four types are the first one is

- The Maccan model.

- The Abyssinian migration model.

- Early Medina model.

- Late Medina model.

\section{Rights of Muslims towards Plants and Animals}

The Prophet of Islam (PBUH) said in one of the sayings that even during the war times it is not allowed for the Muslim to cut the trees and kill the animals. Therefore, it is evident that the religion which prohibits its followers about the deforestation even during war times how can the same religion allows the Muslims to spread destruction during the usual times. Regarding the plantation, the Prophet of Islam PBUH said that planting a tree is the charity. A man from the (Bani Israel) who was very sinful but Allah forgave him all the Sins as he gives the water to the thirsty dog. The teaching of the Prophet instructs its followers do not be cruel to the other creations of Allah like cows, camels, birds.

As the Prophet of Islam said that, 'A women entered Hell because she has tied up and did not feed, nor did she let it loose to feed upon the vermin of the earth.

\section{Rights of Muslims towards those who left this World and were once with us}

The teachings of Islam stated that if a Muslim passes through the Graveyard of Muslims, it is the responsibility for him/her to recite the "Duwa", which Prophet has, taught to us. The duwa is as:

"Peace be upon you all, $\mathrm{O}$ inhabitants of the dwellings (i.e. the graves), amongst the believers and the Muslims. Indeed we are, Allah willing, soon to follow (to die also), we ask Allah for well-being for us and for you."

\section{Rights of Muslims towards the Creation, which are invisible to us}

In this section, mainly we will discuss that creation that we did not see by our naked eyes however, they remains with us like Angles, and the creation of Jinn. It is clear from the Islamic teachings that Allah has created Jins and humans for only worship, so before the creation of human beings, Jins were lived on the earth.

There is clear message from the Prophet of Islam (PBUH) that does not use the dung and bones of animals for the purification during bathroom because the Prophet PBUH told that it is the food of your Jin brothers. 
Regarding the Angles, the Prophet (PBUH) instructs the followers that do not come in the Masjid when you have eaten the fresh garlic and onion because the smells of these items are disliked by the angles.

Overall, the social structure, which is described in the Islam, is mostly based on the teachings of Islamic monotheism, the peace, mutual respect, Gender justice liberty, accountability. The social engineering models, which are described in the Noble Quran for the betterment of the society, are broadly mentioned in below chapters

- AL- Nissa chapter 4.

- $\mathrm{Al}$-NUR chapter 24.

- Al- Ahzab chapter 33.

- Al- Hujarat chapter 49.

Besides, there is the number of authentic sayings of the Prophet of Islam (PBUH) on this subject in different books of the Hadith.

It is not allowed, in the Islamic teachings, that one can enter the houses of other Muslims without asking the permission the owners of that house. Therefore, Islam also focuses on the protection of privacy of the human beings and instructs its adherents to follow these rules actively.

\section{Conclusion}

The need of the hour is to understand the message of Quran and Sunnah without biased mind towards any group or thought. The duty of every Muslim men and woman who knows this Quran must spread it to those who are ignorant of the actual message of the Islam.

In the present, the Muslims are in the flood of their worldly desires, and we are in a deep sleep and are unaware about the Islamic teachings and authentic Sunnah for which the companions of the Prophet spent their whole lives.

Due to our poor awareness about the authentic Islamic teachings, the pessimistic forces are working day and night against the Islam and are busy in spreading the hate through various means, and are cutting the roots of Muslims.

The Muslim countries should use their strengths to carry the true meaning of the Islam based on the injections of the Quran and authentic Sunnah. However, it is regrettable that these Muslim countries are spreading personality cults, sectarian and factional understanding of religion. These Muslim countries are the worst sufferers of sectarianism, these countries have developed the cliffs of hate against each other, and everyone wants to dominate to another one in this entire process they have forgot the real mission. 